\title{
THE APPLICATION OF THE SHERMAN ACT TO "INTEGRATED" AND "LOOSE" INDUSTRIAL COMBINATIONS
}

\author{
Charles H. Weston*
}

During the latter part of the nineteenth century, the doctrine of laissez faire was woven into the fabric of our constitutional law via the due process clause. Condemnation of restraints and monopolies by the Sherman Act gave expression to this doctrine. Today these off-shoots of laissez-faire doctrine, as embodied both in constitutional law and in the Sherman Act, are under heavy fire. As to the Sherman Act, the efficacy of competition as a regulator of prices is questioned; the evil of too much as well as too little competition is stressed-witness many of the NRA codes; the failure of the antitrust laws to prevent concentration of business in the hands of a few is widely proclaimed.

There is undoubted force in much of this criticism; the present antitrust laws certainly need to be supplemented by additional legislation. These questions, however, lie outside the present subject, which is rather an attempt to analyze court decisions interpreting the antitrust laws, dealing with the decisions from the standpoint of the practicing lawyer seeking some general familiarity with them. After all, they are the tools with which he must work, and sometimes the obstacles he must overcome, in carrying out the basic policy of Congress laid down in the Sherman Act and partially supplemented in the Clayton Act.

The decisions construing the Sherman Act may be roughly classified under two headings-those involving integrated combinations and those involving loose combinations. By integrated combinations is meant those where the restraint of monopolization of commerce flows from the possession or acquisition of property rights. This group includes all cases where iwo or more independent concerns are brought under common ownership or control by an acquisition of stock or assets; all mergers or consolidations; and all cases where a corporation and its subsidiaries and affiliates possess power to exercise monopolistic control over prices or otherwise to restrain trade and commerce, irrespective of any recent direct absorption of competitors. Loose combinations embrace all instances where concerns not linked together by

- A.B., I914, LL.B., I916, Harvard University. Member of the Pcnnsylvania and District of Columbia Bars. Special Assistant to the Attorney General, Antitrust Division, United States Department of Justice. since I929. Author of Actions Against the Property of Sovereigns (1919) 32 HaRv. L. REv. 266. 
common property interests either agree to suppress competition among themselves or agree to unite in imposing restrictions upon the activities of third persons. Cases involving trade associations are, of course, typical of this group.

In connection with this classification, it is interesting to note the shift which has occurred in the relative importance of the two types of combination. In the early days of the Sherman Act, the great antitrust cases were, for the most part, cases of integrated combinations. In contrast, not a single case of an integrated combination has come before the Supreme Court during the last ten years. Various factors seem to have contributed to this shift in emphasis.

When the Sherman Act was passed in 1890 , and for a good many years thereafter, techniques later employed for mitigating many of the rigors of competition had not been fully developed. For example, open announcement of prices and terms, exchange of statistical information, price leadership, trade association activity, and extensive advertising designed to persuade the public to buy on the basis of brand or name rather than price, had not grown up. In the earlier period competition was both more ruthless in its methods and more potent in its effects, and the desire to eliminate competition through securing a substantial monopoly of the trade or industry was consequently more intense. The semi-monopolistic combinations achieved or attempted in this early period are reported in such cases as the Standard $\mathrm{Oil}^{1}$ and American Tobacco Co. ${ }^{2}$ cases in the Supreme Court, and the American Can Co., ${ }^{3}$ Corn Products Refining Co., ${ }^{4}$ and International Harvester Co. ${ }^{5}$ cases in the district courts.

At present the more subtle forms of restraint resulting from loose agreements are those with which we are usually most concerned, but the court decisions dealing with integrated combinations are not for this reason no longer important. The recent Appalachian Coals $^{B}$ case shows that decisions involving integrated combinations are sometimes pertinent precedents in determining the legality of loose combinations. Moreover, several cases, recently brought by the Government show that many occasions still exist for questioning the legality of integrated combinations. There is the suit now being tried to bring about the dissolution of the Aluminum Company, and the suit which has recently been instituted against Columbia Gas and Electric. The proceeding against the major motion-picture companies raises issues pertaining both to integrated and to loose combinations.

Before taking up the cases on integrated combinations, a word should be said about the Rule of Reason. Perhaps the most important thing to know about this so-called rule of interpretation is that it is really not a rule of interpretation at all in the sense that it supplies any reliable index to the meaning of the statute. But

\footnotetext{
1 Standard Oil Co. of N. J. v. U. S., 22 I U. S. I (IgII).

2 U. S. v. American Tobacco Co., 221 U. S. 106 (I9II).

${ }^{8}$ U. S. v. American Can Co., 230 Fed. 859 (D. Md. I916); 234 Fed. Iorg (D. Md. I916).

¿U. S. v. Corn Products Refining Co., 234 Fed. 964 (S. D. N. Y. Igr6).

U. S. v. International Harvester Co., 214 Fed. 987 (D. Minn. I9r4).

- Appalachian Coals, Inc. v. U. S., 288 U. S. 344 (I933).
} 
consideration of the motives which led the Court to adopt this rule opens up the nature of the problem of.interpretation with which the courts were confronted when they came to apply the Sherman Act, and serves as a useful introduction to an examination of the actual decisions under the Act. Therefore an attempt will be made to outline briefly the nature of this problem and certain possible solutions.

On the one hand, the Sherman Act covers the entire field of interstate and foreign commerce, and every conceivable variety of commercial conduct and practice is, therefore, within its general scope. On the other hand, the Act is wholly lacking in detailed specification of the conduct which it proscribes; its prohibitions are couched in such vague and general terms as restraint of trade and monopolization of commerce, language which, as Chief Justice Hughes said in the Appalachian Coals case, "has a generality and adaptability comparable to that found to be desirable in constitutional provisions." Furthermore, the legislative history of the Act furnishes little enlightenment. The objectives of Congress as disclosed by the debates appear to have been as vague and general as those to be inferred from the language of the Act itself.

Under these circumstances, one possible course, and the one adopted in the early Freight Association ${ }^{\tau}$ cases, was to apply the words of the statute literally. The Act prohibits "every" contract, combination or conspiracy "in restraint of" interstate or foreign commerce. The objection to this construction is that it makes the prohibitions of the Act so comprehensive as to threaten with condemnation normal and ordinary business contracts and agreement. As Mr. Justice Brandeis said in Board of Trade of Chicago v. United States: 8 "Every agreement concerning trade . . . restrains. To bind, to restrain, is of their very essence." The literal construction provoked a vigorous dissent by four justices in the first Freight Association case and the same justices dissented in the second Freight Association case.

If the words of the statute were not to be applied literally, some limiting formula had to be adopted. One possible course was to view the Act as simply codifying the common law and extending it to the field of interstate commerce. The opinion of the Circuit Court of Appeals in the Addyston ${ }^{9}$ case, written by Judge Taft, adopts this view. If this view had prevailed and had been consistently applied, the broad prohibitions of the Act might have been canalized into somewhat rigid and artificial channels, upon the basis of common law precederits of doubtful relevancy, particularly with reference to application of the Act to the large combinations of capital which were in the forefront of the Congressional discussion preceding adoption of the Act.

A third course, and the one adopted in the Standard $\mathrm{Oil}^{10}$ case, was to interpret the common law as prohibiting only acts or contracts which unreasonably restrain trade, and to regard the Act as likewise limited to agreements or combinations in

${ }^{7}$ U. S. v. Trans-Missouri Freight Ass'n, x66 U. S. 290 ( 897 ); U. S. v. Joint Traffic Ass'n, I7x U. S. 505 (1898).

246 U. S. 231,238 (1918).

${ }^{9}$ U. S. v. Addyston Pipe \& Steel Co., 85 Fed. 27 1 (C. C. A 6 th, 1898).

${ }^{10}$ Supra note $\mathrm{I}$. 
unreasonable restraint of trade or commerce. Although it was on the basis of a supposed rule of the common law that the Act was confined to contracts and combinations in unreasonable restraint of trade, the Court appears to have considered that what was or was not an unreasonable restraint of trade within the meaning of the statute was to be determined more on the basis of the evils which Congress intended to prohibit than on the basis of what the common law had denominated unreasonable restraint of trade. The Court, guided "by the light of reason," was to determine ( $\mathrm{I}$ ) the evils at which the statute was aimed and (2) what restraints produced or were likely to produce these evils. These restraints, then, were the unreasonable restraints which the statute condemned.

It is significant that the Rule of Reason erects judicial legislation into a canon of interpretation.

The Court in the Standard Oil case also decided that the Rule of Reason was applicable to Section 2 of the Act, which makes it unlawful to monopolize or to attempt to monopolize interstate commerce. The Court reached this conclusion by assimilating the prohibitions of Section 2 to those of Section $x^{11}$ It said that at common law the terms, "restraint of trade" and "monopolize" were substantially interchangeable. It said that monopolization and attempted monopolization constitute means of effecting the unreasonable restraint of trade which Section I forbids, and that Congress, in Section 2, had specifically condemned these particular means in order to make sure that they did not escape the general prohibitions of Section I.

In an analysis of integrated combinations, one method of treatment would be to make a generalized statement of the considerations which have been given weight in determining legality or illegality. This method would not, in effect, reflect the Supreme Court's highly empirical approach and course of decision in these cases. Loose combination cases, by way of contrast, fall into fairly distinct categories, and some areas of prohibited conduct and other areas of permissible conduct have been rather well defined. The opinions in the integrated combination cases deal for the most part with disputed questions of fact and of factual inferences, and very little "law" emerges from the decisions, and what little does so emerge does not form a consistent or coherent whole. Accordingly, it seems better to take up the decisions, case by case, showing the principal facts involved in the leading cases.

There is one general difference between cases of integrated combinations and those of loose combinations which may be noted at the outset. In loose combination cases the Court has repeatedly declared that while the intent of the parties may be relevant to the question of the nature or character of the restraint, such intent is irrelevant to the legality of the restraint. In the integrated combination cases on the other hand, intent or purpose has been considered as being in itself one of the principal factors determinative of the legality of the restraint.

Probably this difference cannot be justified on logical grounds. The weight given to intent in the Standard Oil and American Tobacco ${ }^{12}$ cases was a major con-

\footnotetext{
${ }^{11}$ Supra note $\mathrm{I}$, at 6r-62.
}

${ }^{12}$ U. S. v. American Tobacco Co., 22 I U. S. 106 (IgII). 
sideration in passing upon the legality of those integrated combinations. The loose combination cases followed other precedents, and different principles came to be established. Perhaps the difficulty of formulating satisfactory criteria with respect to the legality of integrated combinations accounts for the weight which has been given to intent.

So much by way of general introduction. Now as to the individual decisions, beginning with those in which integrated combinations have been declared illegal, and then passing to those in which the Court has reached the opposite result.

\section{Decisions Involving Integrated Combinations}

The first integrated combination to come before the Supreme Court was the $K_{n i g h t^{13}}$ case, decided in 1895 . The American Sugar Refining Company had brought under its control $90 \%$ of the sugar-refining capacity of the country. The Court held that this was a monopolization of manufacture, and not a restraint or monopolization of interstate commerce in the products of manufacture. In no subsequent case has there been a like unrealistic refusal to recognize and give effect to the obvious fact that interstate commerce in a commodity is restrained when production of the commodity is subjected to restraint. The case represents one of those judicial vagaries not uncommon in the law, and now is of no more than historical importance as far as antitrust proceedings are concerned. Perhaps today even its dicta as to the extent of the commerce power of Congress are equally obsolete.

In the Northern Securities ${ }^{14}$ case, decided ten years later, a holding company had been formed to acquire the controlling stock of two competing interstate railroads. The Court held that the pooling of profits, resulting from common ownership, necessarily operated to eliminate competition between the two subsidiary railroads, and that the Act made it illegal to bring about elimination of this competition. The dissent by Mr. Justice Holmes, in which three other justices concurred, is interesting as showing an interpretation of the Sherman Act which, if it had prevailed, would have greatly limited the scope of the Act with respect to integrated combinations. He contended that the only agreement which had been made was one to exchange stock of the two railroads for stock of the holding company; that such an "exercise of an ordinary incident of property" was not within the intended prohibition of Congress; that the restraint the Act prohibited was "external" restraint, that is, restraint imposed upon persons not parties to the agreement, and that it did not include "an arrangement by which competition is ended through community of interest."

In the Standard Oil ${ }^{15}$ case, decided in rgri, there was also a holding company. In I89g the authorized capital stock of the Standard Oil Co. of New Jersey had been increased by $\$ 100,000,000$. It then acquired the stock of numerous other corporations. The interesting fact about this acquisition, however, is that the stock of the com-

${ }^{13}$ U. S. v. E. C. Knight Co., 156 U. S. I (1895).

${ }^{16}$ Northern Securities Co. v. U. S., I93 U. S. I97 (I904). $\quad{ }^{15}$ Supra note I. 
panies which were acquired had all been subject to a common control, not only immediately preceding the transfer to Standard Oil of New Jersey, but for a period antedating the passage of the Sherman Act. In this case, therefore, when the Court held the combination illegal, it in effect held that the mere continued existence of the corporate combination, in view of the purpose for which it had been formed and the manner in which it had exercised its power, constituted a violation of the Act.

Since there is a rather general notion that integrated combinations are illegal only when competition has been destroyed by uniting or absorbing competitors, and since the Standard Oil case seems to refute any such notion, it may be well to review briefly the corporate history of the enterprise.

The first Standard Oil Company was formed in Ohio in 1870 , and the individuals in control of the company rapidly brought numerous competitors under their control. In 1882 they executed a trust instrument in which they were named as trustees, and they created various controlled corporations (including Standard Oil of Ohio) the stock of which was transferred to the trustees for certificates of beneficial interest. Each stockholder so exchanging his stock received an undivided interest in all the stock held by the trustees, and the trust thus served precisely the same purposes and accomplished the same results as a holding company. In fact the reason why they did resort to the trust device rather than that of the holding company was probably because of the limitations which state laws had imposed on maximum capitalization and ownership of stock in other corporations. The trustees continued to exercise actual control over the stocks vested in them until I899 when, as previously stated, Standard Oil of New Jersey, one of the controlled corporations, was utilized as a holding company and acquired the stock which the trustees had previously controlled.

Reference has already been made ${ }^{16}$ to the Rule of Reason which the Court adopted in the Standard Oil case. How did it apply this rule to the facts in the case before it? The Court failed to state its conclusions on many of the charges made by the Government as to acts and conduct of the combination. Thus the Government charged that the Standard Oil group had restrained and monopolized interstate commerce by means of various predatory practices, such as securing rebates from railroads, lacal price cutting which suppressed competition, operation. of bogus independents and espionage upon the business of competitors. The Court did not specifically pass judgment upon the question whether the evidence sustained these charges. It rested its conclusion that the combination unreasonably restrained and monopolized interstate commerce upon two circumstances, (I) the dominating power and control over the oil industry which the combination had attained, and (2) the intent, manifested by its acts, to secure and maintain this mastery by excluding others from the field.

The American Tobacco ${ }^{17}$ case, decided at the same term of Court, adds little to the development of the law. Here there was even more convincing evidence than in

${ }^{10}$ See pp. 44-45, supra.

${ }^{17}$ U. S. v. American Tobacco Co., 22I U. S. 106 (IgIr). 
the Standard Oil case that the end in view was monopolistic control, and that this end had been ruthlessly and aggressively pursued up to the time the Government's suit was filed.

The railroad cases next to be discussed represent applications of the Sherman Act under circumstances where illegality was much less apparent than in the cases previously considered.

In the Union Pacific ${ }^{18}$ case, decided in 1912, the Supreme Court required the Union Pacific to dispose of its controlling stock interest in the Southern Pacific, which it had acquired in rgor. The lines of these two railroads were widely separated, the Union Pacific running from Kansas City via Ogden, Utah, to Portland, and the Southern Pacific from New Orleans via El Paso to Los Angeles, and then up the coast to San Francisco and Portland. Except as to transcontinental traffic, the competition between the two roads was negligible. Moreover, the Union Pacific's control of the Southern Pacific gave it no monopoly of transcontinental traffic; there were five other roads which, with their connections, formed transcontinental lines. Rates were not increased during the period of stock control, and there is no reference in the opinion to any evidence of unlawful intent other than that to be implied from the mere ac quisition of control. The case was decided upon the ground that the consolidation of the two roads, by "destroying or greatly abridging the free operation of competition theretofore existing," restrained interstate commerce within the meaning of the statute.

In the Southern Pacific ${ }^{19}$ case, decided in I922, the Court required the Southern Pacific to give up its control of the Central Pacific, which the Southern Pacific had held continuously since 1885 , either by lease of the Central Pacific properties, or by both lease and stock control. The Central Pacific line ran from San Francisco to Ogden, where it connected with the Union Pacific, and it thus formed with that road a transcontinental route from San Francisco to the East. The basis of decision was that control of the Central Pacific enabled the Southern Pacific to divert traffic from this route to its own line from San Francisco to the East, and that this control illegally restrained interstate commerce because it fettered "the free and normal flow of competition in interstate traffic." But the Southern Pacific's control of the Central Pacific did not fetter any actual competition unless we go back to the situation existing before 1885 , when control began. The decision must, therefore, be regarded as standing for the proposition that creating a situation which would prevent normal competition from coming into existence, in other words, destruction of potential competition, may constitute an illegal restraint of interstate commerce.

In the Reading ${ }^{20}$ case decided in ig20, the Court also.applied the prohibitions of the Act with great rigor. In that case the railroad had been acquiring coal properties in the area which it served since about 1866 . When suit was. brought the rail-

${ }^{18}$ U. S. v. Union Pacific R. R., 226 U. S. 61 (19ז2).

${ }^{10}$ U. S. v. Southern Pacific Co., 259 U. S. 214 (1922).

${ }^{20}$ U. S. v. Reading Co., 253 U. S. 26 (I920). 
road controlled slightly under $25 \%$ of the total national production of anthracite coal. It had also previously combined with other railroads and with coal producers to control about $75 \%$ of the anthracite coal going to market, a combination which the Supreme Court had enjoined in a I912 case. ${ }^{21}$ There was thus evidence of the railroad's monopolistic intent, but its coal holdings, by themselves, would not seem to have given the railroad power to exercise any monopolistic control over prices. The Supreme Court nevertheless said that the road had obtained a position of dominating power "by deliberate, calculated purchase for control" and that "such a power, so obtained, regardless of the use made of it, constituted a menace to and an undue restraint upon interstate commerce." The Court accordingly required a complete severance of the coal properties from the railroad.

The facts in the Lehigh Valley ${ }^{22}$ case closely paralleled those in the Reading case and the Court likewise compelled a divorcement of the coal lands from the railroad.

Turning now to the cases where the Court has refused to dissolve integrated combinations, one finds that these are few in number, but the few undoubtedly have exercised great influence upon the enforcement of the Sherman Act.

The first of these cases is the so-called first United Shoe Machinery ${ }^{23}$ case (although United States $v$. Winslow ${ }^{24}$ is an earlier criminal case growing out of some of the same facts). 'The United Shoe Machinery Company was formed in 1899 as a consolidation of seven companies engaged in manufacturing patented shoe machinery. The Supreme Court approved the lower court's finding that the machinery manufactured by the companies which were consolidated pertained to different branches of shoe manufacture and were therefore complementary, not competitive. It followed from this finding that the consolidation did not destroy competition and the Court said that such monopoly power as United Shoe Machinery Company had obtained flowed from the lawful monopolies of the individual patents which it had acquired. Various acts which the Government relied upon as showing an illegal purpose to monopolize were held not to show such a purpose. As a precedent, this case would not seem to be of general importance, since the decision turned upon the Court's interpretation of disputed issues of fact.

The United States Steel ${ }^{25}$ case was a suit to dissolve the Steel Corporation, which had been organized in rgor to acquire and hold the stock of twelve operating companies previously independent. In the ten years intervening between its organization and the filing of the Government suit, the company's share of the trade had fallen from about $50 \%$ to about $41 \%$, and the business of certain competitors had grown at a much more rapid rate than that of United States Steel. The Court found that the corporation had not engaged in predatory practices, that it had not attempted to oppress or coerce competitors, that it encountered genuine and substantial com-

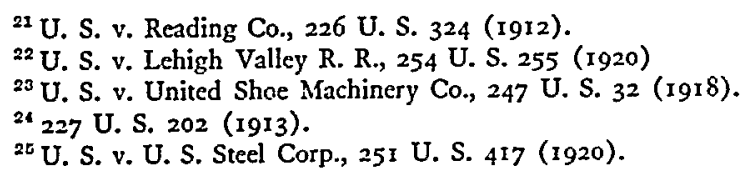


petition, and that while it had been a party to more or less formal price-fixing agree. ments, these had been abandoned before suit was filed, out of a conviction of their futility. The Court therefore concluded that at the time of suit the corporation had neither the purpose nor the power to exact monopolistic prices for its products.

Upon this analysis of the facts, the Government's case was reduced to the single proposition that because of its size the corporation must be regarded as a combination in unreasonable restraint of trade. The Court's answer was that the Sherman Act does not make "mere size" or "the existence of unexerted power" an offense.

Here again, as in the Shoe Machinery case, the decision turns primarily upon the Court's view of the facts rather than upon any particularly novel or limiting interpretation of the scope of the statutory prohibitions. The authority of the case as a precedent is weakened by the fact that it was rendered by four justices, three dissenting and Justices McReynolds and Brandeis being disqualified. There can be little doubt that, had they been qualified to sit, the decision would have gone the other way.

The International Harvester ${ }^{26}$ case involved the construction of a decree entered by consent after the Government had been successful in the District Court in a Sherman Act proceeding and the company had appealed. The decree required the company to dispose of three of its branded harvester lines and limited it to one sales representative in any one city. It also provided that the United States might later seek such further relief as "shall be necessary . . . to bring about a situation in harmony with law." The case came before the Supreme Court on the Government's attempt to obtain such further relief.

Although the Harvester Company had been formed in Ig02 to acquire all the assets of five of the largest companies manufacturing harvesting machinery, the Court took the view that any charge that the combination was illegal by reason of the competition eliminated when the company was formed had been disposed of by the entry of the consent decree. The question whether the Harvester Company was a combination in illegal restraint of trade was therefore treated as being the same as if the position in the industry which the company held when the consent decree was entered had been attained by ordinary growth, unaided by absorption of competitors.

The Court found that the prohibitions of the decree had been effective in increasing competition; that the company had not endeavored to drive competitors out of business, and that between I9Ir, when the litigation started, and I923, when the supplementary proceeding was begun, the company's share of business had fallen from $77 \%$ to $64 \%$. The Court, in effect, held that control over this portion of the trade did not, when unaccompanied by otherwise unlawful conduct, establish any violation of the Sherman Act. It also said that there was no suppression of competition merely because competing firms, as a matter of business expediency, had fixed prices at approximately the same.levels as those set by the Harvester Company.

Having thus surveyed the cases, what conclusions can be drawn? The chief factors given consideration in integrated combination cases seem reasonably clear.

${ }^{28}$ U. S. v. International Harvester Co., 274 U. S. 693 (1927). 
Without attempting to enumerate them in order of importance they are: (I) elimination of substantial competition through union of competitors or absorption of competitors; (2) possession of a position of dominance in the industry (dominance is apparently not to be tested by mere percentage of control, but turns upon whether or not there exist substantial outside competitors and whether, irrespective of substantial outside competitors, the combination has the power to exact a monopolistic price for its products, a price above that which would prevail if prices were determined by competition among free and independent sellers); (3) intent to attain such a position of dominance or intent to exclude competitors, as manifested by absorption of competitors or by use of unfair tactics against them; and (4) use of the dominant position, when attained, to suppress competition either by coercive or oppressive tactics directed against competitors, or by agreements not to compete.

The exact weight given these factors has seemed to vary considerably from case to case. The weight of any one factor is, of course, somewhat dependent upon the presence or absence of the other factors mentioned.

The discussion of the integrated combination cases can fittingly end with this statement made by one commentator after a review of the cases of integrated combinations:

There is support in the body of authority for almost every position that might conceivably be taken; contrariwise, there are embarrassing holdings and dicta which no one theory can fully explain, short of regarding the cases as fundamentally opposed to one another. ${ }^{27}$

\section{II}

\section{Decisions Involving Loose Combinations}

The cases on integrated combinations, as demonstrated above, are difficult, if not impossible, to reconcile, and the courts have evolved no satisfactory formula for testing the legality of these combinations. There is not the same degree of uncertainty in the law with respect to loose combinations. The cases mark out certain fairly well-defined areas of prohibited conduct, and other defined areas of permissible conduct.

Generally speaking, the restraints imposed by loose combinations are of two kinds, those that are self-imposed, where two or more persons combine to limit their own competition, and those that are coercive, where two or more persons take common action against a third person in order to influence or control the latter's conduct. The two types of restraints are quite distinct, although they may both spring from the same combination. Thus, if certain corporations agree to sell at uniform minimum prices, thereby eliminating price competition among themselves, they are likely to try to protect themselves against outside competition by acting in concert to compel corporations which are not parties to the agreement to observe the same minimum sales prices.

Many self-imposed restraints which limit competition are entirely reasonable and unquestionably legal. If there has been a needless and wasteful multiplication of styles

${ }^{27}$ Handler, Industrial Mergers and the Anti-Trust Laws (1932) 32 CoL. L. Rev. 179, 242. 
in a particular industry, because of competitive attempts to capture public fancy, an agreement to limit and standardize styles and quality will cut off one form of competition, but it does not unreasonably restrain interstate commerce. Coercive restraints, on the other hand, are nearly always unlawful, primarily because the means by which they are effectuated, i.e., boycotts, violence, threats, are ordinarily unreasonable, if not unlawful. The use of such unlawful or unreasonable means may be sufficient to make the restraint unreasonable and unlawful.

Of the two types of restraints, those which are self-imposed cover a wider range, and are of considerably greater importance.

\section{A. Self-Imposed Restraints}

\section{(I) Price-fixing Agreements}

Price-fixing agreements are a major classification of self-imposed restraints. The first decision by the Supreme Court dealing with price-fixing under the Sherman Act is the Trans-Missouri Freight Association ${ }^{28}$ case. Railroads operating in certain territory had agreed not to depart, without prior notice, from rates approved and adopted by the Association. The Court at that time was of the opinion that the words of the Sherman Act should be literally applied. Accordingly, the Court held that the agreement was illegal, irrespective of whether, as the defendants contended, its purpose was to maintain reasonable rates and to end destructive competition. In the Joint Traffic Association ${ }^{29}$ case the Court, upon like facts, adhered to its previous conclusions.

The chief present importance of these two freight-association cases consists in the manner in which they were fitted into the Rule of Reason in the Standard Oil ${ }^{30}$ case. The Court there said that the character of the restraints imposed in these cases was such as to bring the restraints within the direct prohibitions of the statute and that, under these circumstances, no question as to the reasonableness of the restraints was open for consideration by the courts. The Court thus regarded the restraint imposed by price-fixing as being per se unreasonable and unlawful.

The next landmark in the law with respect to price-fixing is the Trenton Potteries $^{31}$ case. To have the background of judicial decision against which this case was decided, it seems advisable to state in summary fashion the holdings in three of the leading prior cases in which price-fixing agreements had been held to be in unreasonable restraint of trade in violation of the Sherman Act.

In the Addyston ${ }^{32}$ case price-fixing took the form of collusive bidding on ironpipe contracts opened to competitive bidding within a defined geographical area. Although less than half the productive capacity of the country was represented in the combination, the more distant location of the non-member mills and their consequently adverse freight rates made their competition only partially effective.

\footnotetext{
${ }^{28}$ U. S. v. Trans-Missouri Freight Ass'n, 166 U. S. 290 (1897).

${ }^{20}$ U. S. v. Joint Traffic Ass'n, 17I U. S. 505 (1898). ${ }^{80}$ Supra note I.

${ }^{81}$ U. S. v. Trenton Potteries Co., 273 U. S. 392 (1927).

32 Addyston Pipe \& Steel Co. v. U. S., I75 U. S. 2 I I (1899).
} 
Within the limits set by this competition, the combination conferred upon the parties the power to increase prices.

In the Standard Sanitary ${ }^{33}$ case manufacturers controlling $83 \%$ of the product in which they dealt (enameled ironware bathroom fixtures) entered into an agreement to maintain uniform prices. Each manufactuser had taken out a license under patents held by the secretary of the trade association, and the price agreement was entered into under the guise of observing the price restrictions provided for in the patent licenses. The Court refused to be blinded by this subterfuge and recognized the arrangement for what it was, a direct price-fixing agreement.

In the American Column and Lumber ${ }^{34}$ case the defendants were members of a trade association composed of certain manufacturers of hardwood lumber. Only $5 \%$ of the total number of mills in the industry were members of the association and they controlled only one third of the total production of hardwood lumber. The evidence did not show an agreement to charge any specific minimum prices, or to set any specific limit upon production, but the Court found that the purpose and effect of the activities of the trade association and its members were "to restrict competition . . . by concerted action in curtailing production and in increasing prices." The Court, in holding that this constituted a combination in illegal restraint of interstate commerce, condemned an agreement relating to price, but falling short of actual price-fixing, by a minority group in an industry.

This is the background of the Trenton Potteries ${ }^{35}$ case. There the manufacturers of $32 \%$ of a certain product had entered into a combination to fix and maintain uniform prices for the sale of this product. The Supreme Court held that the trial court did not err in charging the jury that it might find the defendants guilty without regard to the good intentions of the parties, or the reasonableness of the prices fixed, or whether prices were actually lowered or raised. The portion of the charge which the Supreme Court particularly considered and to which the opinion is directed reads:

an agreement on the part of the members of a combination controlling a substantial part of an industy, upon the prices which the members are to charge for their commodity, is in itself an undue and unreasonable restraint of trade and commerce. ${ }^{36}$

The Court said that while the Sherman Act has been interpreted as prohibiting only unreasonable restraints, it does not follow that agreements to fix or maintain prices are reasonable restraints "merely because the prices themselves are reasonable." Reasonableness not being "a concept of definite and unchanging content," the Court's view of what is a reasonable restraint is "controlled by the recognized purpose of the Sherman Law itself." This law, as the Court said, is "based upon the assumption that the public interest is best protected from the evils of monopoly and price control by the maintenance of competition." Accordingly, whether the restraint imposed by an agreement to fix or maintain prices is reasonable or not "must be judged in part at least in the light of its effect on competition."

ss Standard Sanitary Mfg. Co. v. U. S., 226 U. S. 20 (1912).

s4 American Column \& Lumber Co. v. U. S., 257 U. S. 377 (1921).

${ }^{26}$ Supra note 3 r.

${ }^{36} 273$ U. S. 392 , at 396 . (Italics supplied.) 
Following this general discussion of the principles which should.govern decision, the Court said:

The aim and result of every price-fixing agreement, if effective, is the elimination of one form of competition. The power to fix prices whether reasonably exercised or not, involves power to control the market and to fix arbitrary and unreasonable prices." ... Agreements which create such potential power may well be held to be in themselves unreasonable or unlawful restraints, without the necessity of minute inquiry whether a particular price is reasonable or unreasonable as fixed and without placing on the Government ... the burden of ascertaining from day to day whether it has become unreasonable through the mere variation of economic conditions. Moreover, in the absence of express legislation requiring it; we should hesitate to adopt a construction making the difference between legal and illegal conduct ... . depend upon so uncertain a test as whether prices are reasonable-a determination which can be satisfactorily made only after a complete survey of our economic organization and a choice between rival philosophies. ${ }^{37}$

One important question relating to the Sherman Act is whether this statement of the law and of the principles governing its interpretation is modified by the Appalachian Coals $^{38}$ case. In that case 137 producers of bituminous coal, located within a defined producing area, had agreed to market their coal exclusively through a common selling agency, at prices determined by the agency. The defendants' output was about $64 \%$ of the commercial production in their own and the immediately surrounding territory, and about $12 \%$ of the total production east of the Mississippi River. In the principal markets for defendants' coal, they met severe competition from coal from other regions. There also existed vast deposits of bituminous coal in all their producing areas which could quickly and easily be brought into production. And it was also shown that the developed capacity of the industry was greatly in excess of existing demand, and that the selling agency would serve to alleviate certain marketing practices which gave buyers an unfair advantage over sellers.

Upon these facts the Court found that, although the agreement would tend to raise prices to a higher level than would otherwise obtain, the defendants would not have "monopoly control of any market, nor the power to fix monopoly prices." The Court said that, under these circumstances, the mere fact that defendants had eliminated competition among themselves was not sufficient to bring their agreement within the condemnation of the Act. The Court, after noting that the defendants insisted, upon the authority of the Steel ${ }^{39}$ and Harvester ${ }^{40}$ cases, that there would have been no violation of the Act if they had eliminated competition among themselves by a complete integration of their properties in a single ownership, impliedly accepted the analogy of those cases. It said that a co-operative undertaking by independent units may, like the bringing of independent units into one ownership, be prompted by business exigencies, and that the question in either case is whether there is an unreasonable restraint of trade or an attempt to monopolize.

If the case is to be interpreted as approving price-fixing by a minority group in

${ }^{37} I d$., at 397-398. (Italics supplied.)

${ }^{38}$ Appalachian Coals, Inc. v. U. S., 288 U. S. 344 (I933).

${ }^{30}$ Supra note 25.

so Supra note 26 . 
an industry, it runs counter to the trend of previous opinions. In the American Column and Lumber ${ }^{41}$ case the defendants constituted a minority group, although the fact that this combination operated in a period of rising prices, whereas that in the Appalachian Coals case was formed in a period of falling prices, may partially account for the difference in decision. In the Trenton Potteries ${ }^{42}$ case the Court convincingly stated the objections to making legality turn upon so uncertain and difficult a test as the reasonableness or unreasonableness of the prices which were agreed upon. In the Appalachian Coals case the principal ground the Court gave for holding that commerce was not unreasonably restrained was that the combination lacked the power to exact monopoly prices. But is not determination of this question fraught with as great difficulty as the determination of reasonable price? The question can be tested by applying it to bituminous coal. The choice of the consumer is dictated by a combination of such factors as the adaptability of particular grades of coal to his needs, the f.o.b. mine price, and cost of transportation from the mine. What measuring rod can be applied to determine at what point an increase in price in one producing area, brought about by eliminating the price competition of a great number of producers, will cause nearby consumers to shift from this source of supply to other sources, or to other kinds of fuel? How much of that price increase can be attained before the combining producers can be said to have the power to charge a monopoly price?

Whether the Court in future decisions will veer toward the Trenton Potteries case or the Appalachian Coals case remains an open question. The former course seems the more likely. The Appalachian Coals case was decided in early 1933, at a time when the country was near the bottom of one of the worst depressions in its history. The agencies of Government and business were alike engaged in efforts to arrest the downward spiral of prices. The industry concerned was one composed of small units, and it had long been a declining or "sick" industry.

A further question not yet settled is whether the holding in the Trenton Potteries case applies to combinations having both the purpose and the power to control the market price of a commodity, if the means by which such control is sought and obtained takes a form other than an agreement to sell at uniform prices. Since the economic consequences of such a combination are the same as those produced by an ordinary price-fixing agreement, it would seem immaterial that the machinery of price control is different. The Court has only recently declared that the Sherman Act "aims at substance," that its restrictions "are not mechanical or artificial," and that its general phrases are to be "interpreted to attain its fundamental objects." 43

(2) Price Uniformity

Somewhat different from price-fixing agreements are those restraints involving price uniformity. Many of the activities of loose combinations relate to price uniformity, but before considering the cases involving such activities, it is well to get a picture of the conditions which make for uniformity in price.

\footnotetext{
11 U. S. v. American Column \& Lumber Co., 257 U. S. 377 (x92I).

${ }^{43}$ Stipra note 31. $\quad{ }^{3}$ Appalachian Coals, Inc. v. U. S., supra note 6, at $360,377$.
} 
Industrial products are usually sold on the basis of prices and terms which are openly announced to the trade, and which continue until new prices or terms are announced. Since no major unit in an industry can maintain a price for a standardized product if it is appreciably above that openly offered by any other major unit, a price reduction by one is immediately followed by all others. When one major unit advances its price, this furnishes both invitation and incentive to other major units to adopt the same higher price. The smaller the number of major units and the greater the gap between them and the "small fry," the more certainly do these results follow.

This system of uniform prices, with its tendency toward attenuated price competition and relatively high prices, if it is to operate with full effectiveness, requires three conditions in addition to standardization of product and open price announcement, (a) adherence by sellers to their openly announced prices and terms, (b) uniformity in those terms or methods of sale which affect the ultimate cost of the product to the buyer, and (c), which is chiefly important if there are a large number of units in the industry, a medium for the prompt and accurate interchange of information concerning the prices obtained or quoted by the principal producers, as well as other data showing the relation of demand to production. The legality of steps taken by trade associations to bring about some or all of these conditions contributing to price uniformity has been presented in a number of cases.

(a) Adherence to published prices. The cases indicate that an agreement to adhere, or practices which have the effect of securing adherence, are illegal. In the American Linseed ${ }^{44}$ case the members of a trade association interchanged all published price lists. They also agreed to adhere to their published prices, except that terms more favorable to the buyer might be quoted, provided that immediate telegraphic notice of the quoted terms and the buyer's name was given the trade association, which promptly relayed this information to the other members. This kind of an agreement plainly operated to prevent departure from published prices, and the Court had little difficulty in concluding that its "necessary tendency" was to suppress competition.

In the Sugar Institute ${ }^{45}$ case the Institute members agreed to adhere to their published prices until prior public notice of change had been given, and changes were not to become effective until the day after announcement. Although one effect of the agreement, and its avowed purpose, was to put an end to secret discriminations in price as between different customers of the same seller, the agreement also had the purpose and effect of aiding the Institute members in preventing types of transactions in which private negotiation was essential, i.e., long-term contracts. The Court acutely observed that the more nearly conditions in a trade made for price uniformity, the more important became any shutting off of avenues to, or opportunities for, competition. The agreement to adhere to announced prices, since it cut

\footnotetext{
"U. S. v. American Linseed Oil Co., 262 U. S. 37x (1923).
}

${ }^{45}$ U. S. v. Sugar Institute, Inc., 297 U. S. 553 (1936). 
off some important avenues of this kind, was held to constitute an unreasonable restraint of trade.

(b) Concerted adoption of uniform terms or methods of sale. The Sugar Institute case is the leading authority upon practices of this nature. A partial enumeration of selling terms or sales methods as to which uniformity was concertedly undertaken in that case shows the diverse manner in which competition may manifest itself when a product is standardized and is sold at openly announced prices. The defendants concertedly undertook to sell in certain territory at delivered prices only; to prohibit long-term contracts, quantity discounts, guarantees against price decline during the contract period, tolling (refining, for a charge, raw sugar belonging to a third person), and allowance to customers for the return of used bags; to adopt uniform credit terms; to restrict sales of damaged sugar and frozen stocks, customers' shipment of sugar by private charter, and customers' use of certain transportation privileges, such as transiting and diversion.

The admitted objective of these various undertakings was to extend the uniformity in basic price to every element which might introduce a variation in cost to purchasers. The defendants in the Sugar Institute case contended that the means adopted were reasonably necessary to prevent discrimination between customers, and that this was a valid and legitimate objective. The other side of the picture was that occasions for competition among the producers, afforded by opportunities to bring about a variation in cost to the buyer, were likewise suppressed. This was found to be the purpose and effect of the various undertakings, and they were held to be illegal and were enjoined.

(c) Interchange of information concerning prices, production, costs, stocks on hand, etc. The legality of such interchange seems to depend upon the Court's evaluation of the effect of the program as a whole. If it appears from a survey of all the facts of the particular case that the program seriously curtails, or is likely seriously to curtail, competition, then the program and its component parts are condemned as being in unreasonable restraint of trade. But if the opposite conclusion as to effect upon competition is reached, then the interchange of statistical information is a permissible activity.

Programs for the exchange of statistical information have been considered in five cases in the Supreme Court. They were sustained in two cases and found to be illegal in three.

In the American Column and Lumber't6 case a weekly report of each sale by each member, giving the price and purchaser's name, was circulated, as well as various monthly statistical reports. None of this information was available to buyers. The Court was of the opinion that the interchange of information, supplemented as it was by interpretative comment and recommendations by the secretary of the Association, evidenced an agreement to raise prices and to limit production, and was in illegal restraint of commerce.

${ }^{40}$ U. S. v. American Column \& Lumber Co., 257 U. S. 377 (1921). 
In the American Linseed ${ }^{47}$ case, in addition to the agreement to adhere to published prices and the exchange of price lists, which have been mentioned earlier, there was an exchange of detailed information as to sales and offers to sell. The Court found that the plan as a whole constituted an unreasonable restraint of commerce.

In the Maple Flooring ${ }^{48}$ case the Association sent its members abstract statistical summaries covering stocks on hand, volume of production, new and unfilled orders, quantities sold, prices received in past transactions, and freight rates from a central point of shipment. The summaries did not disclose the identity of sellers or buyers, and the statistics were given wide publicity and sent to governmental agencies. The Court recognized that such information may be the basis for agreement or concerted action to lessen production or to raise prices, but held that, in the absence of proof of such agreement or concert of action, the activities did not unlawfully restrain commerce.

In the Cement Manufacturers ${ }^{49}$ case the members received from the Association, in addition to certain statistical information of the kind considered in the preceding case, information as to buyers who were delinquent in their accounts, and detailed information designed to enable the members to prevent buyers from procuring, when prices were rising, more cement than they were entitled to under their contracts. The Court found that the members were free to act as they chose upon this information, and that it served a legitimate purpose of preventing "the perpetration of fraud" upon the sellers.

In the Sugar Institute ${ }^{50}$ case, exchange of statistical information was a comparatively minor feature. Some of the information collected and given to members, but withheld from buyers, was found to give the refiners an unfair advantage over buyers. The Supreme Court sustained the decree of the District Court enjoining collection and dissemination of this information unless it was made available to the purchasing and distributing trade.

The foregoing decisions are not all of the cases on self-imposed restraints, or even all of the most frequently cited cases, but they will serve as a framework for a more detailed study, as they illustrate the most important kinds of practices which have been considered by the Court.

\section{B. Coercive Restraints}

Coercive restraints in the cases have usually taken the form of strikes of employees, violence or threatened violence, or refusal or deal. The strike cases and the cases of physical violence will not be considered here. The principal concern of this article is the application of the Sherman Act to ordinary commercial relations.

Whether the boycott is regarded as an unreasonable method of effecting a restraint of trade so that any restraint achieved by boycott necessarily becomes an $u n$ -

${ }^{47}$ Supra note 44.

${ }^{18}$ Maple Flooring Manufacturers' Ass'n v. U. S., 268 U. S. 563 (1925).

${ }^{48}$ Cement Manufacturers Protective Ass'n v. U. S., 268 U. S. 588 (I925).

${ }^{80}$ Supra note 45. 
reasonable restraint is not definitely settled by the decisions of the Supreme Court. The Court, in condemning boycotts, has stated in general terms that the restraints were unreasonable or illegal, without spelling out the precise basis for this conclusion. In the Sugar Institute ${ }^{51}$ case the District Court appears to have held the view that a restraint by boycott was open to the defense that the restraint was reasonable, but the Supreme Court, by merely affirming the District Court's finding that the boycott there involved resulted in unreasonable restraint, did not even inferentially pass upon the District Court's view as to the law.

While we are thus left without much in the way of guiding principles, and while it may become necessary in future cases to consider such a question as whether the relative strength of the boycotting and boycotted groups is relevant to the legality of a restraint by boycott, a general picture of the scope of the law's prohibitions may be obtained by examining some of the circumstances under which boycotting agreements have been condemned under the Sherman Act.

The early case of Montague \& Co. v. Lowry ${ }^{52}$ typifies an ordinary trade boycott. Eastern manufacturers of tiles and wholesale tile dealers in San Francisco formed an association, the manufacturers agreeing to sell only to members of the association, and the dealers agreeing to buy only from manufacturer members. This combination was held to restrain illegally the interstate commerce of a San Francisco dealer who had not been invited to join and who had not sought to join the association, and who was prevented by the combination from obtaining tiles from manufacturers from whom he had been accustomed to purchase in the past.

The Eastern States Retail Lumber Association ${ }^{53}$ case exemplifies a boycott with an avowed defensive purpose. Various associations of retail lumber dealers circulated among their members a list of wholesalers who sold direct to consumers. The purpose and effect of this was to cause the member retailers to refuse to buy from wholesalers appearing on the so-called blacklist. The defendants contended that their course was "necessary to the protection of the retail trade" and that such protection was in the general public interest. The Court, rejecting this contention, said that the combination effected an unreasonable restraint of trade and that, since Congress had legislated to prohibit undue restraints upon interstate commerce, "private choice of means must yield to the national authority thus exerted."

Two comparatively recent motion-picture cases illustrate the obvious fact that there is an element of self-imposed restraint in combinations to exercise coercive restraint through a boycott. Moreover, the boycotts in those cases were conditional, not absolute. The agreements were to refuse to deal unless or until certain third persons complied with the terms and conditions laid down by the combining group.

The principal defendants in the Paramount $t^{54}$ case were the nine leading producers and distributors of motion-picture films. They supplied $60 \%$ of all films displayed

\footnotetext{
${ }^{21}$ U. S. v. Sugar Institute, Inc., 15 F. Supp. 817, 899 (S. D. N. Y. 1934).

${ }^{12}$ I93 U. S. 38 (1904).

${ }^{23}$ Eastern States Retail Lumber Ass'n v. U. S., 234 U. S. 600 (1914).

" Paramount Famous Lasky Corp. v. U. S., 282 U. S. 30 (1930).
} 
in the United States. They agreed upon a standard form of exhibition contract and agreed not to contract for the exhibition of their films except upon the terms of this standard contract. The standard contract contained no provisions governing the price which exhibitors would pay for pictures, or the number or kind of pictures to be contracted for. The feature of the contract which the exhibitors found most objectionable was a provision that all disputes between the contracting parties should be determined by a system of arbitration, specified in detail in the contract.

The self-imposed restraint resulting from this agreement arose from the fact that it prevented the distributors from competing for business by offering exhibitors a contract omitting the objectionable arbitration provision, and the Court's opinion recognizes this element of self-imposed restraint. The Court said that the defendants, by refusing to enter into contracts except upon the standard form, "agreed to restrain their liberty of action." It also said that, in order to establish a violation of the Sherman Act, it is not necessary to show that the challenged arrangement "suppresses all competition between the parties." The opinion does not expressly designate the restraint as a boycott, but it points out that the manifest purpose of the combination was to coerce the exhibitors, and the Eastern States Lumber Association case was given major emphasis among the-authorities cited to show that the restraint was unreasonable and illegal.

In the First National Pictures ${ }^{55}$ case, the same group of distributors had adopted rules designed to compel any purchasers or assignees of a motion-picture theatre to assume the outstanding commitments of the exhibition contracts of the prior owner or assignor. The rules provided that the distributor should not enter into new contracts with such purchaser or assignee without requiring a cash deposit, unless the purchaser or assignee had been given clearance by a local committee composed of representatives of the distributors. The Court, in holding that the combination was illegal under the Sherman Act, gave weight both to the element of self-imposed restraint and to the element of coercive restraint. It said that the obvious purpose of the combination was "to restrict the liberty" of the distributors, and to "secure their concerted action for the purpose of coercing certain purchasers of theatres by excluding them from the opportunity to deal in a free and untrammeled market."

A word of caution in conclusion. I have analyzed the cases under certain headings or categories, but these categories are not fixed or absolute. They are primarily suggestive. Neither these nor any other possible categories precisely define the scope of the law's compass. Its prohibitions are broad, against restraints of trade and monopoly, and, as the Supreme Court has said, the Sherman Act "aims at substance." Although certain types of activity have been found to be within the statutory prohibitions, and there is now a cluster of legal doctrine around some of these types of activity, neither these typical situations nor the legal rules announced in determining them are exclusive. The scope of the law's application remains essentially fluid. And ample opportunity exists to extend the law's reach into regions where its presence has not yet been detected.

${ }^{50}$ U. S. v. First National Pictures, Inc., 282 U. S. 44 (1930). 